\title{
Studies on Pathology and Therapeutic Efficacy of Anthiomaline in Bovine Papillomatosis
}

\author{
Vikas Jaglan*, Prem Singh, Manisha Punia, Deepika Lather and Sandeep Saharan
}

Department of Veterinary Surgery and Radiology, Department of Veterinary Pathology, Lala

Lajpat Rai University of Veterinary and Animal Sciences, Hisar-125004 (Haryana), India

\author{
*Corresponding author
}

\begin{tabular}{|c|c|}
\hline & A B S T R A C T \\
\hline $\begin{array}{l}\text { K e y w o r d s } \\
\text { Anthiomaline, } \\
\text { Pathology, } \\
\text { Papilloma, } \\
\text { Hyperkeratosis. }\end{array}$ & \multirow{4}{*}{$\begin{array}{l}\text { Bovine papillomatosis is a viral disease of cattle characterized clinically by development } \\
\text { of multiple benign tumours termed warts. The diagnosis of bovine papillomatosis was } \\
\text { confirmed by clinical and pathological examinations of the warts. The aim of the present } \\
\text { investigation was to study the pathology of papillomas and to evaluate the therapeutic } \\
\text { efficacy of anthiomaline in bovine papillomatosis. Six buffaloes suspected with } \\
\text { papillomatosis were treated with anthiomaline (lithium antimony thiomalate) at the dose } \\
\text { rate of } 15 \mathrm{ml} \text { deep intramuscularly on alternate days in adult animals and } 7 \mathrm{ml} \text { deep } \\
\text { intramuscularly on alternate days in young ones i.e. calves. Gross and histopathological } \\
\text { examination of the tumour masses revealed five cases of papilloma characterised by } \\
\text { similar lesions of orthokeratotic hyperkeratosis, finger-like papillae with numerous } \\
\text { vacuolating cells with eccentrically placed nuclei and one of leiomyoma. Anthiomaline } \\
\text { was found to be effective in all the cases as no recurrence was observed in follow up study } \\
\text { period of one year. It may be concluded that anthiomaline can be effectively used for } \\
\text { treating cases of papilloma in bovines. }\end{array}$} \\
\hline Article Info & \\
\hline $\begin{array}{l}\text { Accepted: } \\
\text { 17 June } 2018 \\
\text { Available Online: } \\
\text { 10 July } 2018\end{array}$ & \\
\hline & \\
\hline
\end{tabular}

\section{Introduction}

Bovine papillomatosis is an infectious disease caused by bovine papillomaviruses (BPVs) which are non-enveloped double stranded DNA viruses belonging to the Papillomaviridae family. Papillomatosis consist of hyperproliferative lesions affecting both cutaneous tissue and the mucosa. The papillomas may occur in different parts of the body. Six different types of bovine papilloma virus have been characterized (BPV-1 to BPV6). Bovine papilloma can appear in cattle of any age, but it is seen more commonly in young animals of less than two years old and the tumors regress spontaneously due to the animal's immune response without significant scarring (Olson et al., 1992; Campo et al., 1994; Smith, 1996 and Jelinek and Tachezy, 2005).The disease is usually spread by direct contact with infected animal and virus enters through skin by cutaneous abrasions. Extensive lesions lead to depreciation in both the aesthetic and economic value of the animal owing to loss of body condition, hide value, increased risk owing to trauma, consequent 
wounds, haemorrhages, myiasis, necrotic dermatitis, mastitis and interference in suckling, milking and coitus. These warts may regress spontaneously or occasionally persist, and, in the presence of additional critical genetic or environmental factors, can progress to cancer. Different methods can be used to treat bovine papillomas. Keeping in view of above facts the present study was conducted to understand the pathology of bovine papillomas and to evaluate the efficacy of anthiomaline in the treatment of papillomatous tumours.

\section{Materials and Methods}

Present study was carried out on six clinical cases of buffaloes suspected of papilloma tumour conditions that were presented to the Department of Veterinary Clinical Complex, Lala Lajpat Rai University of Veterinary and Animal Sciences, Hisar. History and clinical examination of cases was conducted to record age and sex, any bleeding /ulceration, infection/inflammation, regional or distant metastasis and gross appearances. Tissue samples were collected from multiple sites separately in $10 \%$ buffered formalin for histopathological examination.

\section{Histopathological studies}

For pathological examination of the tumours, representative tissues pieces of $3-5 \mathrm{~mm}$ were surgically cut and placed in $10 \%$ buffered formalin subsequently processed by paraffin embedding technique as described by Luna, 1968. The histopathological technique involved fixation, washing, dehydration, clearing, embedding, section cutting, staining and microscopical examination.

The tissue samples were washed in running tap water to remove formalin, processed in ascending grades of alcohol for dehydration and cleared in benzene, infiltrated and embedded in paraffin. The paraffin embedded tissues were cut into 3-4 micron thick section using automated microtome and stained with Hematoxylin and Eosin as per procedure of Luna (1968).

\section{Treatment}

The treatment of the animals affected with papillomatosis was carried out by administration of anthiomaline (lithium antimony thiomalate) at the dose rate of $15 \mathrm{ml}$ deep intramuscularly on alternate days in adult animals and $7 \mathrm{ml}$ deep intramuscularly on alternate days in young ones i.e. calves. The above treatment was repeated for a minimum of six times or till complete recovery. Other supportive therapy included administration of injection of vitamin $\mathrm{C}$ and B-complex.

\section{Results and Discussion}

The details regarding age, sex, gross appearances of the cases are described in table 1 . The results revealed that the age of affected animals ranged from 3 months to 8 years and out of six, three cases were present in male calves and three in adult buffaloes. Clinically, the papillomatous growths with wart/nodule like structures were present on different regions of the body (Fig. 1 and 2). The warts present were either singly or multiple on different regions of body. The nodules were firm, dry and physically hard in four cases, whereas in the other two cases, the nodules were broadly attached at the base giving it an appearance of a circular disc.

\section{Histopathological examination}

Histopathological examination revealed that five out of six cases were of papilloma and one of leiomyoma. The detailed histopathological findings of these cases are described as follows: 


\section{Bovine Papillomas}

Microscopically, papillomas were characterized by orthokeratotic hyperkeratosis, finger-like papillae with numerous vacuolating cells with eccentrically placed nuclei (Fig. 3). The growths were outward papillary projections of stratified squamous epithelium. These papillary projections consisted of different layer of stratified epithelium having keratinized layer on periphery and connective tissue in centre. Most of prickle cell layer have vacuolated cytoplasm. In stratum granulosum cell layer, large number of cells appeared degenerated and also showed vacuolated cytoplasm. Histological features of papillomas in different cases of the present study were almost similar.

\section{Therapeutic efficacy}

The efficacy of anthiomaline in the treatment of bovine papillomatosis was found to be $100 \%$ as all the five affected cases recovered after treatment and there was no report of recurrence even after one year of follow up study.

Table.1 Gross and histopathological description of all tumour cases in bovine

\begin{tabular}{|c|c|c|c|c|c|}
\hline $\begin{array}{c}\text { Case } \\
\text { no. }\end{array}$ & $\begin{array}{c}\text { Animal } \\
\text { species }\end{array}$ & $\begin{array}{c}\text { Age } \\
\text { (Years) }\end{array}$ & Sex & Location & $\begin{array}{c}\text { Histopathological } \\
\text { Diagnosis }\end{array}$ \\
\hline $\mathbf{1}$ & Buffalo calf & 0.3 & $\mathrm{M}$ & Brisket region & Papilloma \\
\hline $\mathbf{2}$ & Buffalo calf & 0.5 & $\mathrm{M}$ & Thigh region & Papilloma \\
\hline $\mathbf{3}$ & Buffalo calf & 0.4 & $\mathrm{M}$ & chest region & Papilloma \\
\hline $\mathbf{4}$ & Buffalo & 8 & $\mathrm{~F}$ & Face region & Leiomyoma \\
\hline $\mathbf{5}$ & Buffalo & 8 & $\mathrm{~F}$ & Eye area & Papilloma \\
\hline $\mathbf{6}$ & Buffalo & 6 & $\mathrm{~F}$ & Base of ear & Papilloma \\
\hline
\end{tabular}

Fig.1 and 2 Bovine Papilloma: Papillomatous growths with wart/nodule like structures on different regions of the body

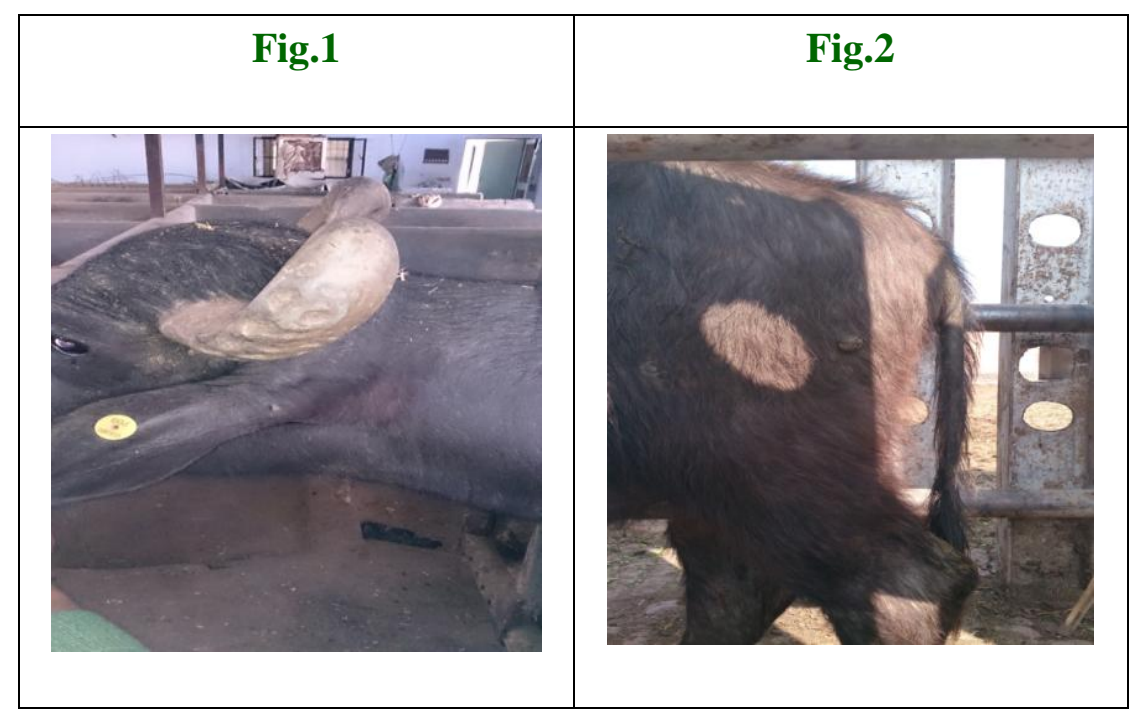


Fig.3 Bovine Papilloma: Photomicrograph of bovine papilloma characterized by orthokeratotic hyperkeratosis (black arrow), finger-like papillae with numerous vacuolating cells with eccentrically placed nuclei. (H \& E stain X100).

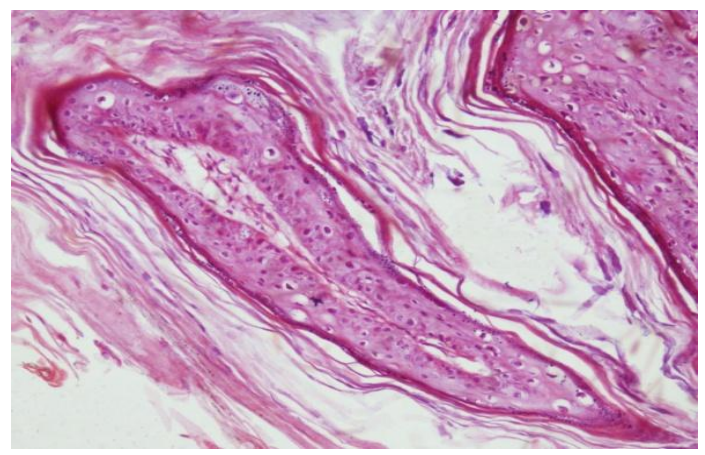

Bovine papillomatosis is contagious in animals in which it naturally occurs and is caused by six different serotypes of epitheliotropic. Bovine papilloma viruses (BPVs) having double stranded DNA as viral genome distinguished by their restriction endonuclease cleavage. Amongst the cutaneous affections as encountered in bovine calf crops, benign cutaneous neoplasm (tumours) or warts caused by BPVs forms a most common clinical entity. It can be defined as benign nodular lesions, finger like projections or cauliflower like small growths on the skin arising from stratified squamous epithelium. It may be single (solitary) or appear in multiples (Jana and Mukherjee, 2013). The common sites for the development of cutaneous warts are head, eyelids, ears, neck, dewlap, brisket, shoulders and legs, occasionally on the back, para-genital region and along the lower line of abdomen (Miller and West, 1972; Aiello, 1988; Smith, 1996). Bovine cutaneous papillomas were observed mainly on the head and neck, but in some animals localisation in other parts of body has also been reported (Cimtay et al., 2003; Atasever et al., 2005). In present study the age ranges from 0.3 to 8 years and the sites for papilloma were brisket, eye, ear, back and thigh. Kavithaa et al., 2014 studied 24 Jersey cows aged 6-8 years at Erode District of Tamil Nadu. The disease affects young animals more often and more severely, but may affect cattle of all ages (Olson, 1993; Smith, 1996 and Nicholls and Stanley, 2000). Affected cattle were usually less than 2 years old and the tumours regress spontaneously within one year (Olson et al., 1992; Campo et al., 1994; Smith, 1996 and Jelinek and Tachezy, 2005). In present study the affected animals were in contact with each other. Although the spread of the disease was usually by direct contact, many factors such as contaminated food and equipment, castration, injections, inheritance, nutritional imbalance, hormonal imbalance, and suppressing the immune system may play roles in the spread of disease (Campo et al., 1994; Dinc, 1995; Nicholls and Stanley, 2000; Otter and Leonard, 2003). Histopathologically, varying degrees of hyperplasia of the epidermis with irregular papillary projections into the dermis was common and it was seen in all animals. In the epidermis moderate to severe acanthosis, mild to severe hyperkeratosis, hydropic degeneration of keratinocyts and many koilocytes with variably sized keratohyalin granules were present. Also rare presence of intranuclear inclusion bodies was observed only in the basal cells of the epidermis. Dermis showed mild to moderate hyperplasia of the connective tissue that consisted of blood vessels, fibroblasts, focal hemorrhage 
and mild infiltration of lymphocytes. The microscopic findings of the tumor that observed in the present study were similar to those described. The literature reveals that papillomas occur most commonly at sites of abrasion where papilloma virus may enter the epidermis and resulting in papillomatous growth (Goldschmidt and Handrich, 2002). Studdert et al., (1998) reported papilloma of ear in calves following tattooing.

For treatment of these cases different methods have been reported like cauterisation, excision, cryotherapy, administration of local anaesthesia, autologous or heterologous vaccination, and autohaemotherapy or use of drugs for the nonspecific stimulation of the immune system (Bajric et al., 1983; Amin et al., 1997; Silva et al., 1998). Bajric et al., (1983) has reported papillomas to regress completely in the majority of cattle undergoing administered autohaemotherapy 3-4 times at intervals of 7-10 days. Biricik et al., (2002) has reported following the administration of autohaemotherapy for 4 times at an interval of 3 days. Having treated bovine papillomatosis with levamisole at a dose of $2.5 \mathrm{mg} / \mathrm{kg} /$ day on days $1,3,5,7,9$ and 16. Cihan et al., (2004) have reported $100 \%$ recovery within $7-12$ days after the completion of treatment. In the present study, animals which were given anthiomaline for six times on alternate day. All animals recovered within 12-14 days after the completion of treatment and there was no report of recurrence. It may be concluded that pathological changes in the papillomas were similar and anthiomaline can be effectively used for treating cases of papilloma in bovines.

\section{References}

Aiello SE (ed.). 1988. The Merck Veterinary Manual. 8th edn. Marck and Co. Whitehouse Station. New Jersey. p.2305.

Amin, D.M., Salem, S.A.H., Ahmed, M.H., Karim, I.A., 1997. Patological and virological studies on bovine papillomatosis in cattle. Egyptian Journal of Comparative Pathology 10, 1-11

Atasever, A., C, Am, Y., Atalay, O., 2005. Bir sigir surusunde deri papillomatosis olgulari. Ankara Universitesi Veteriner Fakultesi Dergisi. 52: 197200.

Bajric, A., Jevtic, S., Ozegovic, T., Dugalic, N., 1983. Autohaemotherapy of bovine papillomatosis. Veterinary Yugoslavia. 32: 79-83.

Biricik, H.S., Keskin, O., C, imtay, I., Baba, Z.F., 2002. Sigir papillomatozisinin tedavisinde otology asi ve otohemoterapi uygulamalarının karsılastırılması. Turkish Journal of Veterinary Animal Sciences .27: 703707.

Campo, M.S., Jarrett, W.F., O'neil, W., Baron, R.J., 1994. Latent papillomavirus infection in cattle. Research in Veterinary Science. 56: 151-15

Cihan, M., Ozaydin, I., Ozba, B., Varan, V., 2004. Clinical effects of levamisole in bovine papillomatosis. Indian Veterinary Journal . 81: 321-323

Cimtay, I., Biricik, H.S., Keskin, O., Baba, Z.F., 2003. Comparative studies on the efficacy of different vaccination methods in the treatment of bovine papillomatosis. Turkish Journal of Veterinary Animal Sciences . 27: 929933.

Dinc, D.A.,1995. Papillomatozis. In: Evcil Hayvanlarda Memenin Deri Hastalıkları, Dolasim Bozukluklari ve Operasyonlari. Konya, Ulku Matbaasl, pp. 41-45.

Jana, Debasis. and Mukherjee, Samir Kr. 2013. Therapeutic management of 
bovines cutaneous papillomatosis with ivermectin in farm bred calf crops of west Bengal, India. Anim. Med. Res., Vol.3, Issue - 2. pp: 123-130

Jelinek F, Tachezy R . 2005. Cutaneous papillomatosis in cattle. J Comp Pathol. 132: 70-81.

Kavithaa, N.V., Rajkumar, N. Vimal. and Jiji, R.S. 2014. Papillomatosis in jersey cows and its different medical treatment. International Journal of Science, Environment and Technology, Vol. 3, No 2. pp: 692 694

Luna, L.G. 1968. Manual of histologic staining methods of Armed Forces Institute of Pathology. $3^{\text {rd }}$ edn., Mc Graw Hill Book Company, New York.

Miller WC, and West GP. 1972. Blacks Veterinary Dictionary, 10th edn. Adam and Charles Black. London. p.106

Nicholls, P.K., Stanley, M.A., 2000. The immunology of animal papillomaviruses. Veterinary
Immunology and Immunopathology. 73: 101-127.

Olson, C., 1993. Papillomatosis in cattle. In: Howard, J.L. (Ed.), Current Veterinary Therapy 3 \& Food Animal Practice. W. B. Saunders Company, Philadelphia, London, Tokyo, pp: 430-431.

Olson, C., Olson, R.O., Hubbard-Van Stelle, S., 1992. Variations of response of cattle to experimentally induced viral papillomatosis. Journal of the American Veterinary Medical Association. 201: 56-62

Otter, A., Leonard, D., 2003. Fibropapillomatosis outbreak in calves. Veterinary Record .1: 570571.

Silva, L.A.F., Jayme, V.S., Oliveira, M.A.B., Eurides, D., Fioravanti, M.C.S., DiasFilho, F.C. 1998. Cutaneous pedicle implant of the papilloma and autohaemotherapy in the treatment of bovine papillomatosis. Veterinaria Noticias. 4: 83-88.

\section{How to cite this article:}

Vikas Jaglan, Prem Singh, Manisha Punia, Deepika Lather and Sandeep Saharan. 2018. Studies on Pathology and Therapeutic Efficacy of Anthiomaline in Bovine Papillomatosis Int.J.Curr.Microbiol.App.Sci. 7(07): 2562-2567. doi: https://doi.org/10.20546/ijcmas.2018.707.300 